
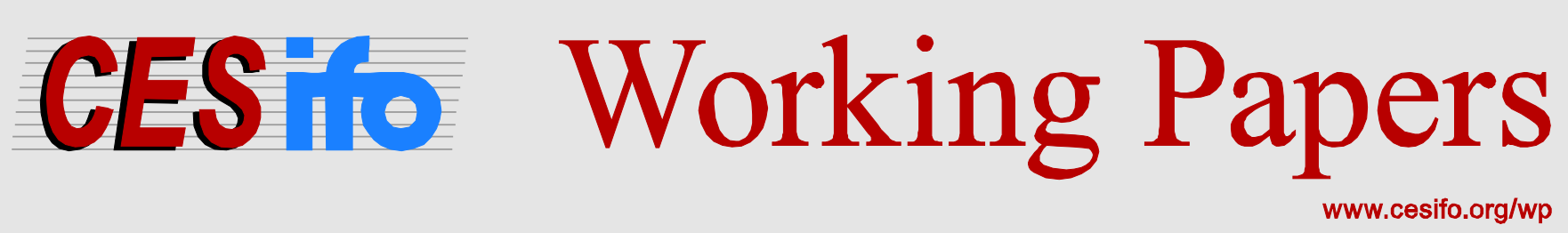

\title{
Fiscal Policy During Business Cycles in Developing Countries: The Case of Africa
}

\author{
Willi Leibfritz \\ Horst Rottmann
}

\author{
CESIFO WORKING PAPER NO. 4484 \\ CATEgory 6: Fiscal Policy, Macroeconomics AND GROWTH \\ NOVEMBER 2013
}

An electronic version of the paper may be downloaded

- from the SSRN website:

- from the RePEc website:

- from the CESifo website:

WwW.SSRN.com

Www.RePEc.org

www.CESifo-group.org/wp

\section{CESifo}




\title{
Fiscal Policy During Business Cycles in Developing Countries: The Case of Africa
}

\begin{abstract}
Fiscal positions of African countries have improved significantly during the past decade. Higher economic growth, better terms of trade, improved donor support notably through debt relief and better control of expenditure contributed to this improvement. But at the same time government revenue and expenditure have become more volatile. The paper explores behaviour of government spending during business cycles. It finds that spending has on average been since 1980 broadly a-cyclical thus neither significantly aggravated nor mitigated cyclical fluctuations. But when comparing the two sub-periods before and after 2000 we find that before 2000 spending was on average (moderately) procyclical. While from 1980 to 2000 in almost two thirds of the 46 countries, which we examined, spending was procyclical this share declined to less than 40 percent after 2000 and in the majority of countries spending was a-cyclical or countercyclical. As more countries escaped from procyclicality Africa's resilience against external shocks improved. This also helped to better cope with the Great Recession of 2009.
\end{abstract}

JEL-Code: O110, O230, H300, H500.

Keywords: developing countries, Africa, fiscal policy, business cycles.

Willi Leibfritz

Fritz-Lutz-Strasse 4

Germany-81929 Munich

willi.leibfritz@web.de
Horst Rottmann

University of Applied Sciences

Amberg-Weiden

Hetzenrichter Weg 15

Germany-92637 Weiden

h.rottmann@oth-aw.de

November 2013 


\section{Introduction}

Over the last decade Africa's economic performance has significantly improved. Economic growth has accelerated, inflation has declined and fiscal positions have improved. While African countries are still affected by internal and external shocks the continent has also shown a remarkable resilience to such shocks. At the same time it has been argued that in developing countries in general and in Africa in particular domestic policies, notably government spending, aggravate rather than mitigate boom-bust cycles, which may also have slowed the catching up process (Ilzetski and Vegh 2008, Carmignani 2010).

This paper examines this issue. It first describes the development of government revenue, expenditure and fiscal balances over the past three decades and then takes a closer look at spending behaviour during business cycles. For this aim we estimate for Africa as a whole and for 46 individual countries cyclical deviations from trend for government expenditure and real GDP. We then calculate correlation coefficients between these deviations to find out if these are positive or negative, which indicates procyclical or countercyclical spending behaviour. We also examine if and how spending behaviour has changed over time.

\section{Long term improvements of fiscal positions}

During the past decades African countries achieved significant improvements in government budgets. The five-year annual averages of Africa's (GDP-weighted) average fiscal balance reveals a clear trend towards fiscal consolidation. Africa's fiscal deficit, which had amounted to 7 per cent in the 1980s, declined steadily during the 1990s and the 2000s and during 20062010 it was close to zero. This latter period included some years with surpluses during the economic boom from 2004 to 2007 but also a large deficit of above 5 per cent during the global recession in 2009. Since then Africa's average fiscal position has again improved. Africa's fiscal consolidation since the 1990s was largely achieved by higher revenue. While public expenditures declined (as per cent of GDP) during the 1990s they later increased again and are now back to the levels of the early 1980s but are now much closer to revenue levels (Figure 1). This successful fiscal consolidation was helped by several factors. Government revenues were boosted by improved tax collection and rising tax bases due to higher commodity prices and higher economic growth; Africa's trend growth increased from only 2 per cent during the 1980s and the early 1990s to around 5 per cent during the past decade (AfDB et al. 2010; AfDB et al. 2013; Leibfritz and Flaig, 2013). At the same time better controls and various debt relief programmes, which reduced interest payments, contained spending growth. 
Figure 1: Fiscal development since the 1980s in Africa

(Per cent of GDP)

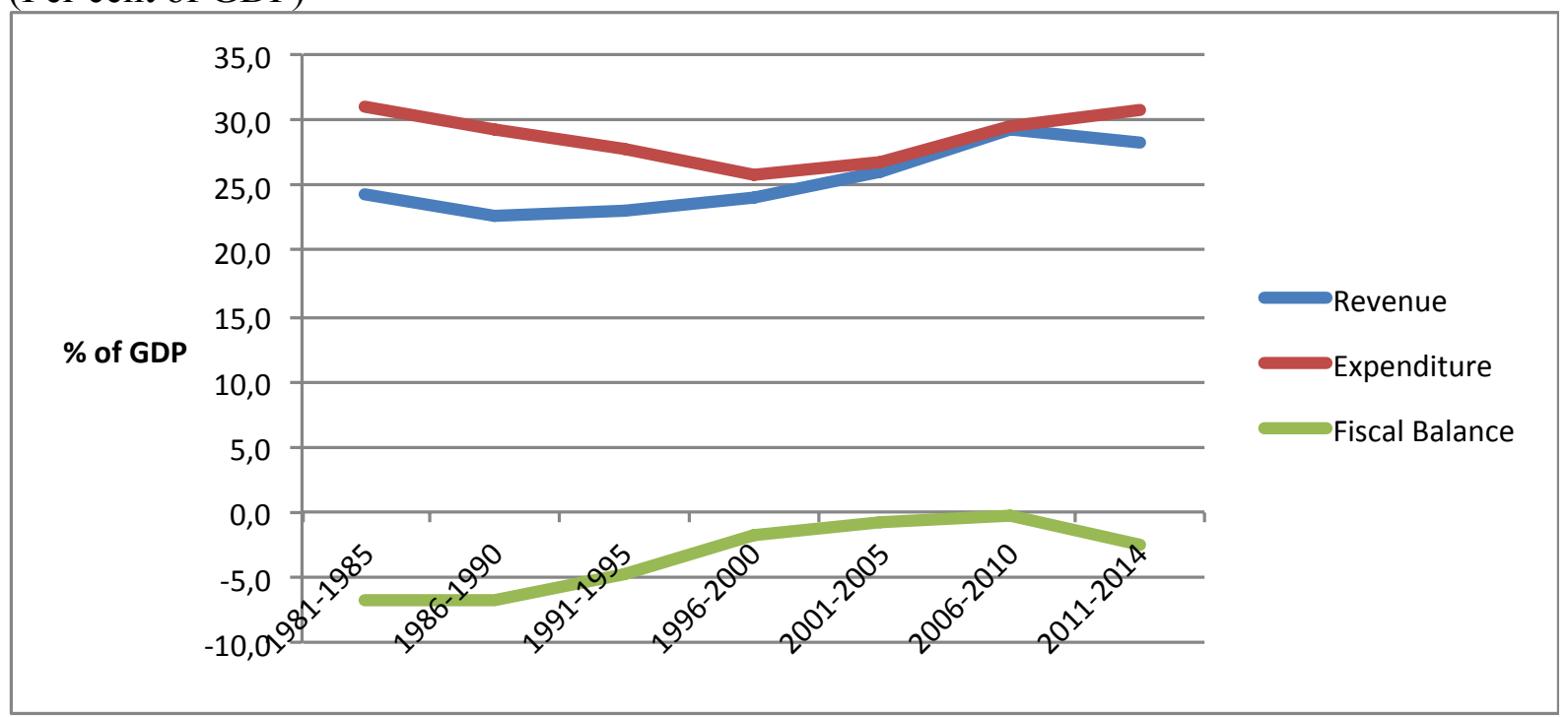

Source: African Development Bank and author's calculations. 2013 and 2014 are estimates by the African Development Bank.

Fiscal consolidation was widespread in Africa but in oil-exporting countries it was more pronounced than in oil-importing countries. The reason was, that in oil-exporting countries revenues increased more (benefiting from higher oil prices) and spending was more contained than in oil-importing countries (Figures 2 and 3).

Figure 2: Fiscal development since the 1980s in African oil-exporting countries (Per cent of GDP)

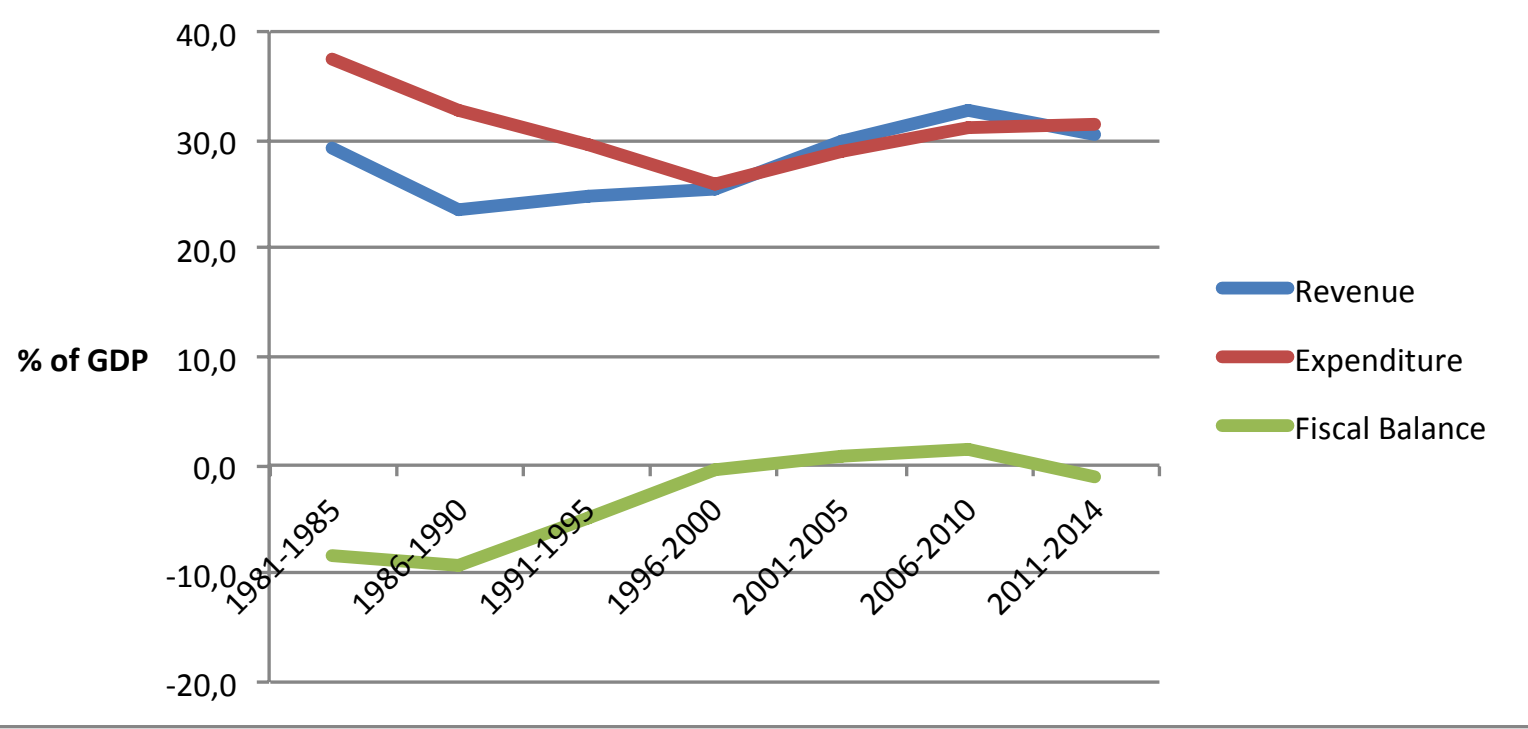

Source: African Development Bank and author's calculations. 2013 and 2014 are estimates by the African Development Bank. 
Figure 3: Fiscal development since the 1980s in African oil-importing countries (per cent of GDP)

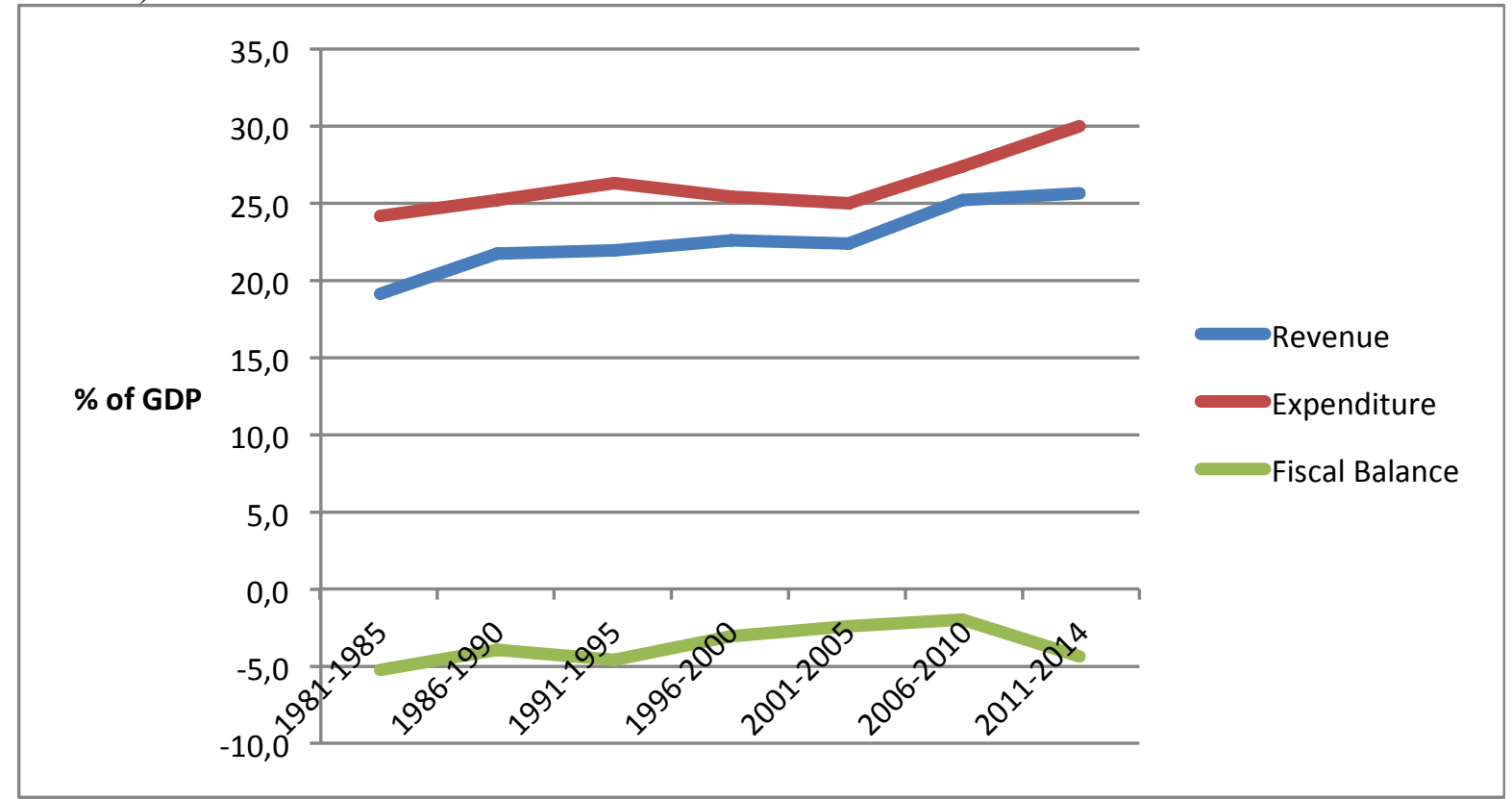

Source: African Development Bank and author's calculations. 2013 and 2014 are estimates by the African Development Bank.

\section{Fiscal policies and business cycles}

While fiscal positions have on average clearly improved in Africa since the 1980s and the 1990s government revenues, expenditures and fiscal balances (as percentages of GDP) became more volatile after 2000 . At the same time GDP growth accelerated but became less volatile (Table 1). The combination of increasing revenue volatility and declining growth volatility is somewhat surprising. One reason may be that the boom-bust development of commodity prices during the last decade caused sharp movements in the terms of trade so that the terms of trade adjusted GDP (command GDP), which determines government revenues, fluctuated more than GDP (AfDB et al., 2013). An increased resilience of African countries against external shocks and less frequent internal shocks such as political or military conflicts may also have contributed to lower growth volatility. In the following we examine if government spending contributed to improve Africa's resilience against economic shocks. This question cannot be answered by simply looking at spending volatility. Its increase after 2000 could have been caused by the higher revenue volatility, thus reflecting procyclical spending but it could also reflect countercyclical spending, which may then have contributed to the lower growth volatility. 
Table 1: Average developments and fluctuations of government revenue, expenditure and fiscal balances in Africa

\begin{tabular}{|c|c|c|c|}
\hline & 1981-1990 & $1991-2000$ & 2001-2013 \\
\hline & \multicolumn{3}{|c|}{$\%$ of GDP } \\
\hline Revenue & 23,5 & 23,6 & 27,9 \\
\hline Expenditure & 30,2 & 26,8 & 28,9 \\
\hline Fiscal Balance & $-6,8$ & $-3,3$ & $-1,0$ \\
\hline \multicolumn{4}{|l|}{ Memorandum item } \\
\hline \multirow[t]{2}{*}{ GDP growth in \% } & 2,6 & 2,9 & 5,3 \\
\hline & \multicolumn{3}{|c|}{ Standard deviation } \\
\hline Revenue & 1,41 & 1,12 & 2,24 \\
\hline Expenditure & 1,61 & 1,52 & 2,30 \\
\hline Fiscal Balance & 1,04 & 1,94 & 2,82 \\
\hline \multicolumn{4}{|l|}{ Memorandum item } \\
\hline GDP growth & 1,27 & 1,90 & 1,11 \\
\hline
\end{tabular}

Source: African Development Bank and author's calculations.

\subsection{Keynesian or non-Keynesian effects of fiscal policies?}

If fiscal policy has Keynesian effects an increase of expenditure or a reduction of taxes increases output while cutting expenditure and raising taxes reduces output. In this case pursuing countercyclical policies could smooth cyclical fluctuations of the economies. It would then be desirable to adopt expansionary fiscal policies during cyclical downturns and restrictive policies during economic booms. Countries should allow automatic stabilizers to operate i.e. in downturns accommodate cyclical declines in government revenues by increasing debt, and, where additional scope is available, in addition to increase public expenditure to boost aggregate demand (and vice versa during economic booms). However, if fiscal policy has non-Keynesian effects deficit-financed spending programmes are counterproductive. In this case raising public indebtedness to finance public spending would reduce private sector spending through higher interest rates (crowding out) and confidence effects. It may then be even necessary to cut spending during cyclical downturns in response to declining revenues. Whether fiscal policy has Keynesian or non-Keynesian effects depends on the specific circumstances in the country, notably its initial fiscal conditions, notably the initial size of indebtedness but also on the size of the output gap and on financial market conditions. It has been found that in the past fiscal policies in Africa had on average significant Keynesian effects. This means that counter-cyclical fiscal policies would have helped to smooth economic cycles (Ilzetski and Vegh 2008; Carmignani 2010). We now look more closely at spending behaviour during business cycles in order to find out if government spending has been procyclical, a-cyclical or countercyclical.

\subsection{Methodology}

We analyse the cyclicality of government expenditure vis-à-vis output and not the cyclicality of the whole budget. The reason behind that is the endogenous character of tax receipts with respect to the business cycle and that public spending better reflects discretionary fiscal policy 
(Kaminsky et al., 2004; Dabla-Norris et al., 2010) In the following we calculate correlation coefficients between the cyclical fluctuations of government expenditure and of real GDP (deviations from their trends) since 1980 and for the sub-periods before 2000 and after 2000. A positive correlation between cyclical fluctuations of spending and of GDP indicates procyclical spending behaviour and a negative coefficient points to countercyclical behaviour. We estimate the trends by using the Hodrick-Prescott filter (Hodrick/Prescott, 1997). A crucial point with this approach is to select an appropriate value for the smoothing parameter $\lambda$. There are different views about the appropriate value for the smoothing parameter $\lambda$ (Hodrick/Prescott, 1997; Ravn/Uhlig, 2002; Flaig, 2012). We follow Leibfritz and Flaig (2013) and use for our annual data of GDP and expenditure $\lambda=30$. We also tested the sensitivity of the correlation coefficients for a lower smoothing parameter $(\lambda=7)$. But the correlation between the country specific correlation coefficients using $\lambda=7$ and the $\lambda=30$ is very high (0.96). As there are no major difference we present here only the correlation coefficients based on the trend estimates with $\lambda=30$.

For the cyclical fluctuations of government expenditure we use alternatively the development of nominal government expenditure ratios (percentage of GDP) and the development of real expenditure levels. Expenditure ratios can be directly taken from the statistical database of the African Development Bank (AfDB). The development of real government spending has been derived from the development of expenditure ratios by making the simplifying assumption that changes of expenditure deflators are similar as changes of GDP deflators. Using this assumption we can calculate the development of real government expenditure by multiplying the expenditure-GDP ratios with the real GDP.

\subsection{Overall results}

Table 2 shows the overall results for Africa. The correlation coefficients are shown for the aggregate approach where the coefficients have been directly derived from development of Africa's total government expenditure and GDP and a disaggregate approach where Africa's correlation coefficients have been calculated as unweighted and GDP-weighted averages from the coefficients of 46 individual countries. We define a noticeable procyclical spending behaviour if the correlation coefficient between cyclical fluctuations of real government spending and of real GDP is 0.22 or higher, a noticeable countercyclical spending if the correlation coefficient is -0.22 or lower and a-cyclical spending if the correlation coefficient is between 0.22 and $-0.22^{1}$. When comparing the deviations of expenditure-GDP ratios and of real GDP from their trends we find negative correlation coefficients for the whole period. By contrast, when using real expenditure levels instead of expenditure ratios the correlation coefficients are for the whole period positive. But in both cases the correlation coefficients are relatively small (between 0.22 and -0.22 ) thus suggesting a-cyclical spending. When comparing the periods before and after 2000 we see some differences between the expenditure ratio and the expenditure level approach as some of the correlation coefficients are outside the range, which we define as a-cyclical. As the two different approaches lead to different results ${ }^{2}$ one has to decide which one is more reliable. We prefer the second approach

\footnotetext{
${ }^{1}$ With 33 observations per country and a significance level of ten percent we can refuse the null hypothesis that the correlation between to two cycle variables is zero if the estimated correlation coefficient $\rho$ is absolutely greater than 0.22 , because $\rho\left(\frac{1-\rho^{2}}{33-2}\right)^{-0.5} \stackrel{\text { a }}{\sim} \mathrm{N}(0,1)$

${ }^{2}$ Because the correlation between the country specific correlation coefficients of the two different approaches is about 0.85 , countries with the smallest (highest) correlation coefficients with one approach have also usually the
} 
with real spending levels. The reason is that even if spending would develop along its trend, i.e. exhibit no cyclical effects, the expenditure ratio would increase during recessions and decline during economic booms, owing to lower (higher) GDP growth (Kaminsky et al., 2004). The correlation coefficient between the cyclical component of the expenditure ratio and of output would then be negative and indicate - incorrectly - countercyclical spending behaviour. Indeed, when comparing the results of these two approaches, we find in many cases that with the first approach (the expenditure ratios) the correlation coefficients have often a negative although with the second approach the correlation coefficients are positive. A drawback of our preferred second approach is, however, that the development of real government spending had to be estimated by using simplistic assumptions about expenditure deflators, which may affect the results.

With our preferred approach with expenditure levels we find for the period before 2000 that two of the three indicators (aggregate approach and unweighted average of individual countries) indicate procyclical spending while one indicator (GDP weighted average) points to a-cyclical spending. For the period after 2000 the correlation coefficients are lower and all three indicators point to a-cyclical spending. Other studies (Ilzetski and Vegh 2008; Carmignani 2010) have found procyclical spending behaviour in developing countries including Africa. In contrast to these studies we cannot confirm that spending continued to be significantly procyclical after 2000 thus having seriously aggravated business cycles. While spending behaviour has become less destabilizing after 2000 it has - on average - been acyclical thus neither aggravated nor mitigated cyclical fluctuations.

Table 2: Correlation coefficients between cyclical fluctuations of government expenditure and of real GDP in Africa

\begin{tabular}{|l|l|l|l|}
\hline & $\begin{array}{l}\text { Whole } \\
\text { period } \\
\text { since } \\
1980\end{array}$ & $\begin{array}{l}\text { Before } \\
2000\end{array}$ & $\begin{array}{l}\text { After } \\
2000\end{array}$ \\
\hline $\begin{array}{l}\text { Expenditure-to-GDP ratios } \\
\text { Aggregate approach }\end{array}$ & $-0,10$ & $-0,06$ & $-0,11$ \\
Average of countries (unweighted) & $-0,07$ & $-0,03$ & $-0,12$ \\
Average of countries (GDP-weighted) & $-0,16$ & $-0,07$ & $-0,33$ \\
\hline Real expenditure levels & & & \\
Aggregate approach & $+0,19$ & $+0,31$ & $+0,15$ \\
Average of countries (unweighted) & $+0,18$ & $+0,25$ & $+0,11$ \\
Average of countries (GDP-weighted) & $+0,10$ & $+0,17$ & $-0,05$ \\
\hline
\end{tabular}

Source: African Development Bank and author's calculations.

Our finding of improved spending behaviour during recent years is also confirmed by looking more closely at spending behaviour during the 2009 global recession. While Africa's average government revenue share of GDP declined significantly the expenditure share increased leading causing the fiscal balance to swing from a surplus during the preceding boom period into a high deficit. The deterioration of the fiscal balance was most marked oil-exporting countries (Table 3 ).

smallest (highest) correlation coefficients with the other approach. The rank of the countries changes only slightly. 
Table 3: Fiscal developments in Africa during the global recession 2009 (Per cent of GDP)

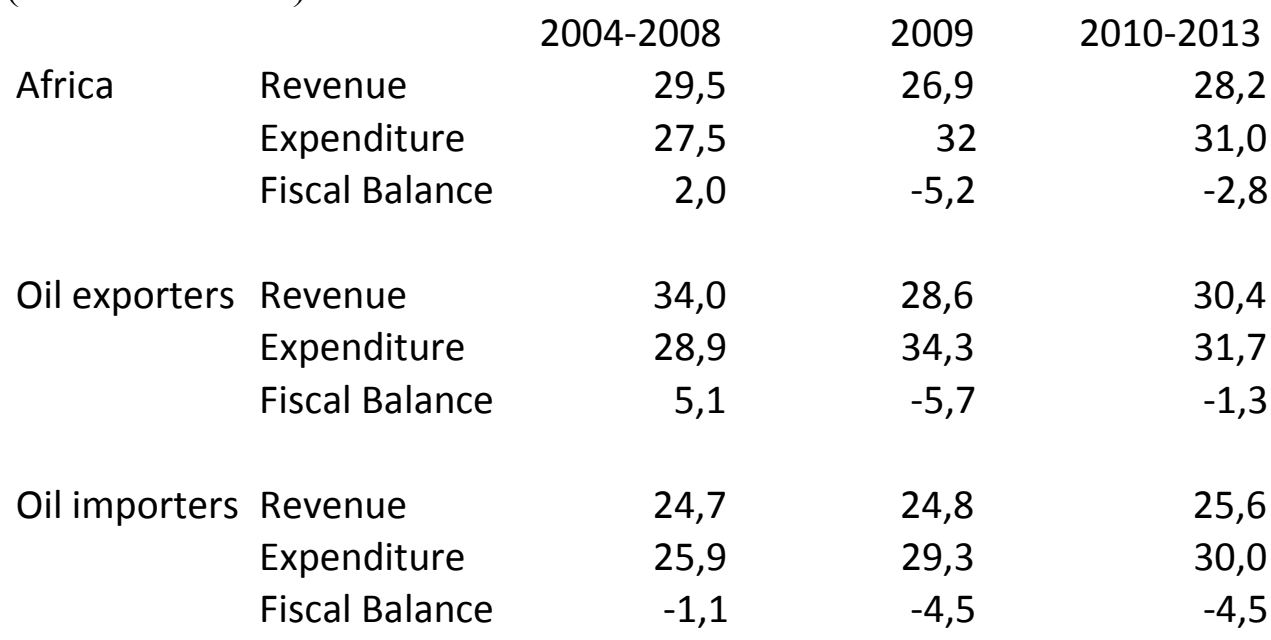

Source: African Development Bank, author's calculations.

The higher expenditure shares in GDP point to countercyclical spending behaviour but, as mentioned above, could also partly be the result of lower GDP. In order to better assess spending behaviour during the global recession Table 4 shows the fluctuations of real public expenditure and of real GDP around their trend before and after the global recession in 2009. In 2009, government spending in Africa (and in the two groups of oil-exporting and oilimporting countries) was on average countercyclical as the average real expenditure level was significantly above its trend. But it declined to below trend in 2010 although GDP continued to be slightly below trend.

Table 4: Cyclical fluctuations of real government spending and of real GDP in Africa (Deviations from trend in per cent)

\begin{tabular}{|l|r|r|r|r|}
\hline & 2007 & 2008 & 2009 & 2010 \\
\hline Africa & & & & \\
GDP & 1.43 & 1.56 & -0.40 & -0.39 \\
Government expenditure & -3.82 & 7.52 & 5.95 & -0.75 \\
\hline Oil exporting countries & & & & \\
GDP & 1.38 & 1.42 & 0.18 & -0.03 \\
Government expenditure & -3.76 & 10.22 & 9.15 & -0.76 \\
\hline Oil importing countries & & & & \\
GDP & 1.45 & 1.73 & -0.98 & -0.59 \\
Government expenditure & -3.99 & 2.60 & 2.19 & -0.46 \\
\hline
\end{tabular}

Source: African Development Bank and author's calculations.

\subsection{Spending behaviour of individual countries}

Spending behaviour differs a lot across the continent. With our definition of procyclical, countercyclical and a-cyclical spending as mentioned above, we find procyclical spending before 2000 in almost two thirds of countries but this share declined to below 40 per cent after 2000. The shares of countries with countercyclical spending increased slightly after 2000 but remained below one fifth while the share of countries with a-cyclical spending increased from about a quarter before 2000 to 43 percent after 2000. (Table 5) 
Table 5: Number of African countries with procyclical, countercyclical and a-cyclical spending behaviour

\begin{tabular}{|l|l|l|l|}
\hline & Whole period & Before 2000 & After 2000 \\
\hline $\begin{array}{l}\text { Countries with } \\
\text { procyclical spending }\end{array}$ & $22(48 \%)$ & $30(65 \%)$ & $18(39 \%)$ \\
\hline $\begin{array}{l}\text { Countries with } \\
\text { countercyclical } \\
\text { spending }\end{array}$ & $6(13 \%)$ & $5(11 \%)$ & $8(17 \%)$ \\
\hline $\begin{array}{l}\text { Countries with a- } \\
\text { cyclical spending }\end{array}$ & $18(39 \%)$ & $11(24 \%)$ & $20(43 \%)$ \\
\hline $\begin{array}{l}\text { Total number of } \\
\text { countries }\end{array}$ & 46 & 46 & 46 \\
\hline
\end{tabular}

Source: African Development Bank and author's calculations.

Of our sample with 46 countries there is only one country (Tunisia), which had countercyclical spending both before and after 2000. Seven countries improved their policies from procyclical or a-cyclical spending before 2000 to countercyclical spending after 2000 (Algeria, Botswana, Cape Verde, Guinea, Mauritania, Morocco, Nigeria). But seven countries moved in the opposite direction from countercyclical or a-cyclical spending before 2000 to procyclical spending after 2000 (Angola, Benin, Gambia, Libya, Malawi, Sudan, Zambia). In eleven countries spending remained procyclical before and after 2000 (Central African Republic, Djibouti, Egypt, Ethiopia, Lesotho, Madagascar, Mali, Mozambique, Rwanda, Seychelles, Togo). In twenty countries spending remained a-cyclical (Equatorial Guinea, Namibia, Swaziland) or changed from countercyclical to a-cyclical (Chad) or from procyclical to a-cyclical behaviour (Burkina Faso, Burundi, Cameroon, Congo Rep., Congo Dem.Rep., Côte d'Ivoire, Gabon, Ghana, Kenya, Mauritius, Niger, Senegal, Sierra Leone, South Africa, Uganda) (Figures 4-6). ${ }^{3}$

Among the 46 countries, which we have examined, 19 have in the past adopted fiscal rules, either as supranational deficit rules such as the member countries of the West African Economic and Monetary Union (WAEMU) ${ }^{4}$ and the member countries of the Central African Economic and Monetary Community (CEMAC) $)^{5}$ or as national deficit or expenditure rules such as Botswana (since 2003), Cape Verde (since 1998), Kenya (since 1997), Mauritius (since 2008), Namibia (since 2010) and Nigeria (since 2007). It is interesting to note that among the 19 countries in our sample, which have fiscal rules, in three countries spending was counter-cyclical after 2000 (Botswana, Cape Verde, Nigeria), while in twelve countries it was a-cyclical (Burkina Faso, Cameroon, Chad, Congo Rep., Côte d'Ivoire, Equatorial Guinea, Gabon, Kenya, Mauritius, Namibia, Niger, Senegal) and in four countries procyclical (Benin, Central African Republic, Mali, Togo). This finding suggests that having a fiscal rule may help to improve spending policies but it does not shield a country from pro-cyclical fiscal behaviour. Bova et al. (2013) find for advanced countries that the fiscal stance tends to be

\footnotetext{
${ }^{3}$ If we would have defined a-cyclical spending if the correlation coefficient is absolutely smaller than 0.1 instead of 0.22 , and procyclical and countercyclical spending respectively, our main message would not have changed. The share of countries with procyclical spending declines also after 2000 by about 25 percentage points as compared with the period before 2000.

${ }^{4}$ The WAEMU members are Benin, Burkina Faso, Côte d'Ivoire, Guinea-Bissau, Mali, Niger, Senegal and Togo.

${ }^{5}$ The CEMAC members are Cameroon, Central African Republic, Chad, Republic of Congo, Equatorial Guinea and Gabon.
} 
more a-cyclical with a fiscal rule but in developing countries including Africa it remains on average pro-cyclical. These authors suggest that pro-cyclicality has tended to increase in emerging market and developing economies following the adoption of a fiscal rule, a finding, which is not confirmed by our study. Indeed, the majority of the 19 countries in our sample with fiscal rules improved their spending behaviour by changing from procyclical to countercyclical spending after 2000 (Botswana, Nigeria) or from a-cyclical to countercyclical spending (Cape Verde) or from procyclical to a-cyclical spending (Burkina Faso, Cameroon, Congo Rep., Côte d'Ivoire, Gabon, Kenya, Mauritius, Niger, Senegal). Two countries with fiscal rules continued with a-cyclical spending (Equatorial Guinea, Namibia). By contrast in two countries with fiscal rules spending behaviour deteriorated from countercyclical to acyclical spending (Chad) or from a-cyclical to procyclical spending (Benin) and in three countries spending remained procyclical (Central African Republic, Mali, Togo). While our findings differ from those of Bova et al (2013) we do agree with their policy conclusions that in order to prevent pro-cyclicality during recessions and economic booms, fiscal rules should be improved by using cyclically adjusted fiscal targets instead of simple deficit targets and/or including well-defined escape clauses, together with appropriate enforcement arrangements.

Overall our analysis of spending behaviour during business cycles shows that despite significant improvements in recent years finding an appropriate fiscal response to economic shocks remains an important challenge for African countries. Creating fiscal space during economic upturns and ensuring debt sustainability enables countries to follow countercyclical or at least a-cyclical spending policies during economic downturns. 
Figure 4: Correlation Coefficients between cyclical fluctuations of government spending and of GDP in Africa (since 1980)

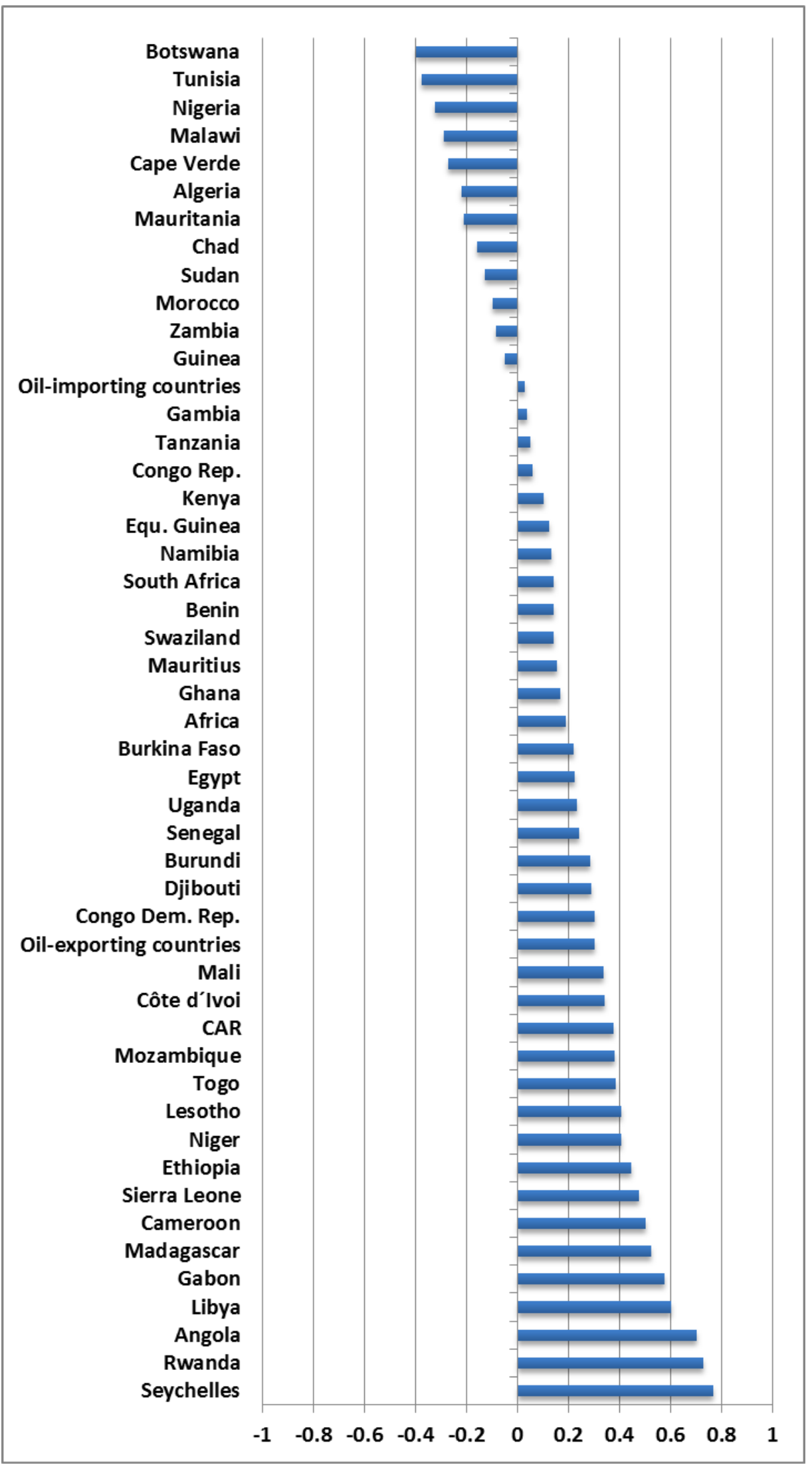


Figure 5: Correlation Coefficients between cyclical fluctuations of government spending and of GDP in Africa before 2000

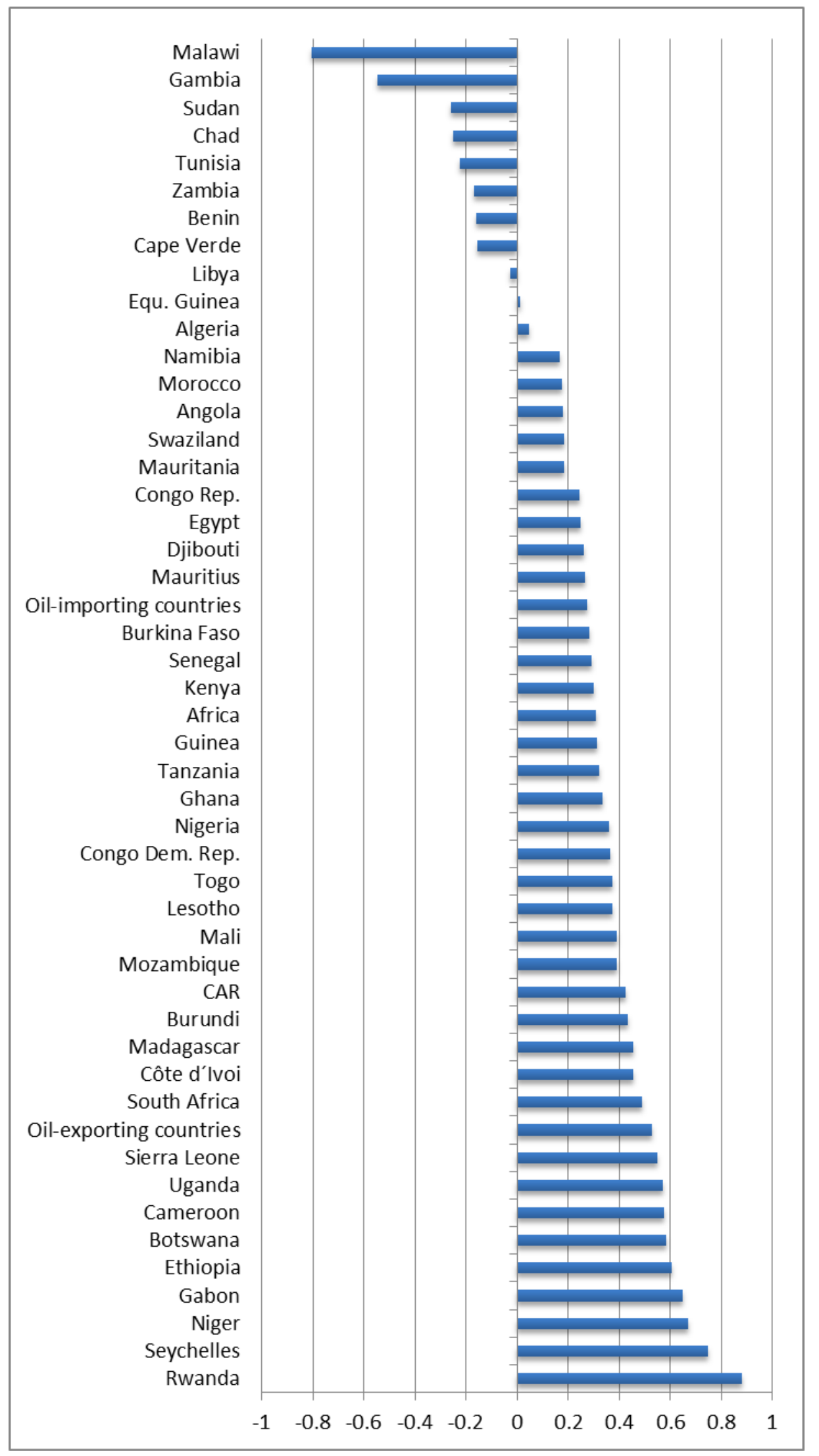


Figure 6: Correlation Coefficients between cyclical fluctuations of government spending and of GDP in Africa after 2000

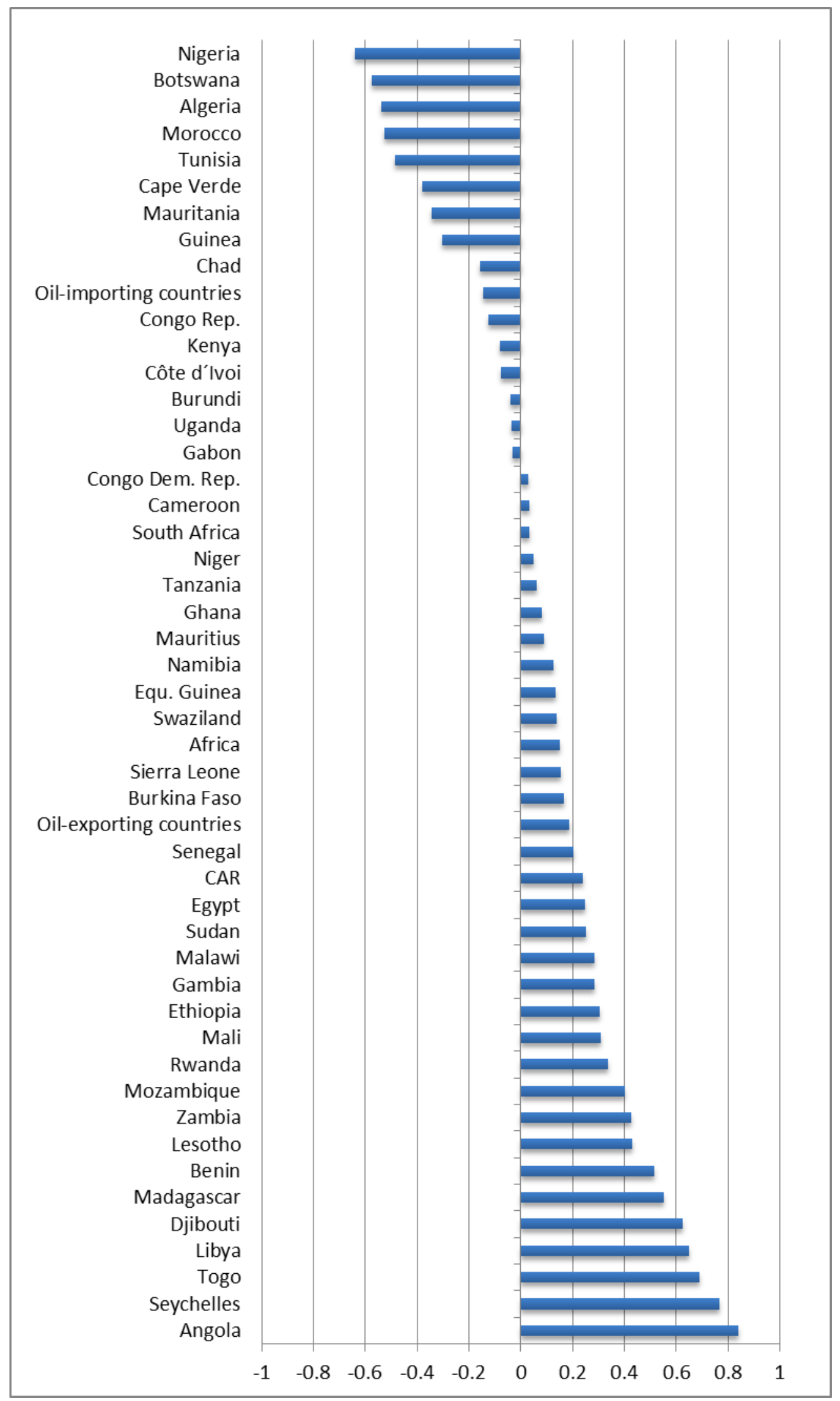




\section{References}

AfDB, OECD, UNDP, ECA (2010), “African Economic Outlook 2010”, OECD Publishing, Paris.

AfDB, OECD, UNDP, ECA (2013), “African Economic Outlook 2013”, OECD Publishing, Paris.

Bova E., N. Carcenac and M. Guerguil (2013), "Fiscal Rules and Procyclicality of Fiscal Policy in the Developing World", Paper presented at the IMF-World Bank Conference on Fiscal Policy, Equity and Long-term Growth in Developing Countries, Washington, DC, April 21-22, 2013.

Carmignani F. (2010), "Cyclical fiscal policy in Africa”, Journal of Policy Modeling, Vol. 32, Issue 2, March-April 2010.

Dabla-Norris, E., R. Allen, L. Zanna, T. Prakash, E. Kvintradze, V. Lledo, I. Yackovlev and S. Gollwitzer (2010), "Budget Institutions and Fiscal Performance in Low-Income Countries," IMF Working Paper 10/80.

Flaig, G. (2012), "Why we should use high values for the smoothing parameter of the Hodrick-Prescott filter". CESifo Discussion Paper 3816.

Hodrick, R. and E. Prescott (1997), "Postwar U.S. Business Cycles. An Empirical Investigation“. Journal of Money, Credit, and Banking, 29, 1-16.

Ilzetski, E., and C. Vegh (2008), "Procyclical Fiscal Policy in Developing Countries: Truth or Fiction?” NBER Working Paper 14191.

Kaminsky G.L. , C.M. Reinhart, C. A. Veh, „When it rains it pours: Procyclical capital flows and macroeconomic policies, NBER Working Paper 10780, September 2004.

Leibfritz, W. and G. Flaig (2013), "Economic Growth in Africa: Comparing Recent Improvements with the "lost 1980s and early 1990s and Estimating New Growth Trends", CESifo Working Paper No. 4215.

Ravn, Morton and Harald Uhlig (2002), "On Adjusting the Hodrick-Prescott Filter for the Frequency of Observations“. Review of Economics and Statistics, 84:2, 371-376. 